DOI: $10.26693 / j m b s 06.06 .080$

UDC 611.98:616-089.11

Tereshchenko A. O.', Shyian D. M. ${ }^{1}$, Olyanich S. O. ${ }^{2}$

\title{
MACRO-MICROSCOPIC FEATURES OF THE LEG MUSCLES INNERVATION
}

\author{
${ }^{1}$ Kharkiv National Medical University, Ukraine \\ ${ }^{2}$ Kharkiv International Medical University, Ukraine
}

The purpose of the study was to disclose topographic anatomical features of the extra- and intramuscular innervation points of the leg.

Materials and methods. 15 adult human subjects and one-month old baby legs at three levels were studied using such methods: cross-sections according to N.I. Pirogov technique, histotopographic sections, macro-microscopic method, histological staining with hematoxylin-eosin and Krutsay.

Results. In our macro-microscopic study, the main attention was paid to the individual anatomical variability in the innervation of the lower leg muscles. Study of the nerves of the leg muscles allowed to clarify the course of the neurovascular bundle of the leg at its three levels, taking into account individual age characteristics, and also to show the myeloarchitectonics of both the main nerve trunks and their intramuscular branches. Such differences in the location of the leg muscles of an adult and of one month-old baby undoubtedly related to the fact that the child's muscular belly is longer in relation to the tendon.

The histotopography of intramuscular nerves on total transverse sections of antagonistic muscles was studied: flexor and extensor digitorum longus, longus flexor and extensor of the big toe, and also the spectrum of myelin fibers contained in these nerves in a one-month-old baby and an adult was investigated.

On histotopographic sections of the extensor digitorum longus nerve in a one-month-old baby, thick-diameter myelin fibers are absent, whereas in the long finger flexor nerve, on average, they are $0.5 \%$. The number of thin and medium is respectively $8 \%, 13 \%$ and $83.5 \%, 16 \%$.

However, we have determined individual anatomical variability in the location of the vessels in relation to the main nerve trunks, as well as differences in the topography of the nerve in the corresponding muscles.

Conclusion. In the nerves of the leg muscles, features were found, both in quantitative and qualitative composition of the conductors forming them; in the nerves of the flexor muscles, the composition of the nerve fibers is more diverse (with a slight predominance of the number of medium, thick and very thick fibers), which is associated with the peculiarity of their functions; in adulthood, the \% ratio in the spectrum of myelin fibers in the nerves of the lower leg changes significantly.
Keywords: tibial nerve, leg muscles, innervation, human.

Relationship of work with scientific programs, plans, and topics. This study is based on the results of the PhD thesis "Morphological features of the nerves of the leg".

Introduction. Developing neurology and reconstructive surgery sciences require morphologists for further investigation of the external structural organization of peripheral nerves, in particular the nerves of the leg muscles. This is primarily due to the improvement of microsurgical techniques and the expanding range of neuro- and myoplastic operations [1-4]. Meanwhile, in classical and modern manuals, as well as in special research data on the surgical anatomy of the leg muscle nerves, there is no complete data on the topography of intramuscular nerves. The question of individual anatomical variability of intraorganic nerves of the leg is not highlighted enough [5-7].

The available studies have mainly identified extreme forms of variability of extraorganic nerves of the leg without the full range of variability of both extraand intraorganic nerves, which is of particular interest to surgeons currently engaged in myo- and neuroplastic operations of the leg [8-10].

The purpose of the study was to investigate the topographic and anatomical features of innervation of human leg muscles.

Materials and methods. We studied the extraand intramuscular nerves of the leg at three levels: at its upper, middle and lower third, using cadaveric material from 15 adult human subjects and one-monthold baby. Methods which were used are cross-sections according to N.I. Pirogov technique, histotopographic sections, macro-microscopic method, histological staining with hematoxylin-eosin and Krutsay.

All experiments were conducted in accordance with the Council of Europe Convention "On the Protection of Human Rights and Dignity of the Human Being with regard to the Application of Biology and Medicine Application of Biological and Medicine Achievements (ETS No. 164)" dated 04.04.1997, and the Helsinki Declaration of the World Medical Association (2008).

Research results and discussion. As a result of the study of extraorganic nerves on preparations of the adult's lower specimens in the upper, middle and lower third of it, the following data was obtained. 
In the upper third of the leg, the tibial nerve and the posterior tibial artery and veins located behind it lie in the cruropopliteal canal between the posterior tibial and soleus muscles. The artery is located laterally to the nerve trunk. The common peroneal nerve runs between the subcutaneous fat cell and the head of the fibula.

In the middle third of the lower leg, the tibial nerve is located between the long flexor of the big toe and the soleus muscle. Vessels lie medially to it. The superficial peroneal nerve is located anteriorly between the superficial and deep peroneal muscles. The deep peroneal nerve runs between the long extensor of the big toe and the interosseous membrane. Vessels are located medially to it.

In the lower third of the lower leg, the tibial nerve lies between the long flexor of the big toe, the long flexor of the fingers and the fascia of the lower leg. Vessels are located medially to it. The data obtained basically coincide with the literature data.

However, we have determined individual anatomical variability in the location of the vessels in relation to the main nerve trunks, as well as differences in the topography of the nerve in the corresponding muscles. The latter should be taken into account in the practice of acupuncture.

The topography of the extra- and intramuscular nerves in the region of the middle third of the adult's leg, as well as in a 1-month-old child, has been studied in more detail.

In adulthood, the tibial nerve is located between the long flexor of the big toe and the soleus muscle. An artery and vein are sequentially located medially to it.

In a 1-month-old baby, as well as in an adult tibial nerve is located in the cruropopliteal canal. However, in a 1-month-old baby unlike an adult, in the middle third of the leg, the nerve is located between the posterior tibial and soleus muscles (Fig. 1).

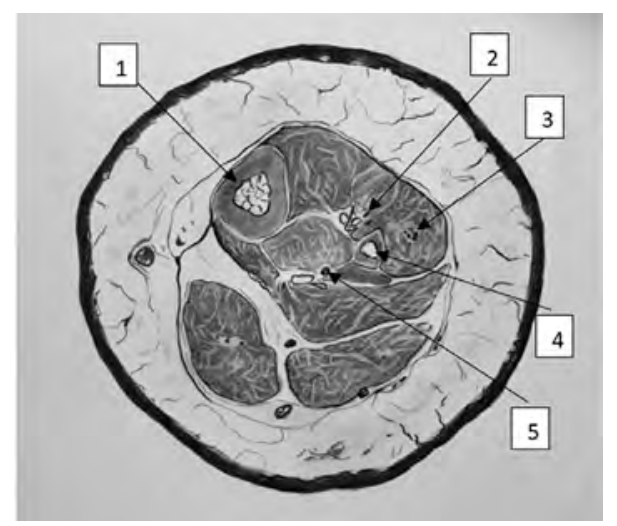

Fig. 1 - Histotopography of the nerves of the leg muscles at the level of its middle third. 1-month-old baby. Right limb

Notes: 1 - tibia; 2 - deep peroneal nerve; 3 - superficial peroneal; 4 - fibula; 5 - tibial nerve
The posterior tibial artery and two veins in succession lie in front of the nerve.

Superficial peroneal nerve in a 1-month-old baby is located between the deep and superficial peroneal muscles in their middle part, surrounded by vessels, while in adults it is displaced forward.

In one-month-old baby the deep peroneal nerve is located between the long extensor of the fingers and the big toe, the vessels are closer to the interosseous membrane and medial to it. In adults, the deep peroneal nerve lies between the long extensor of the big toe, the tibialis anterior muscle, and the interosseous membrane (Fig. 2).
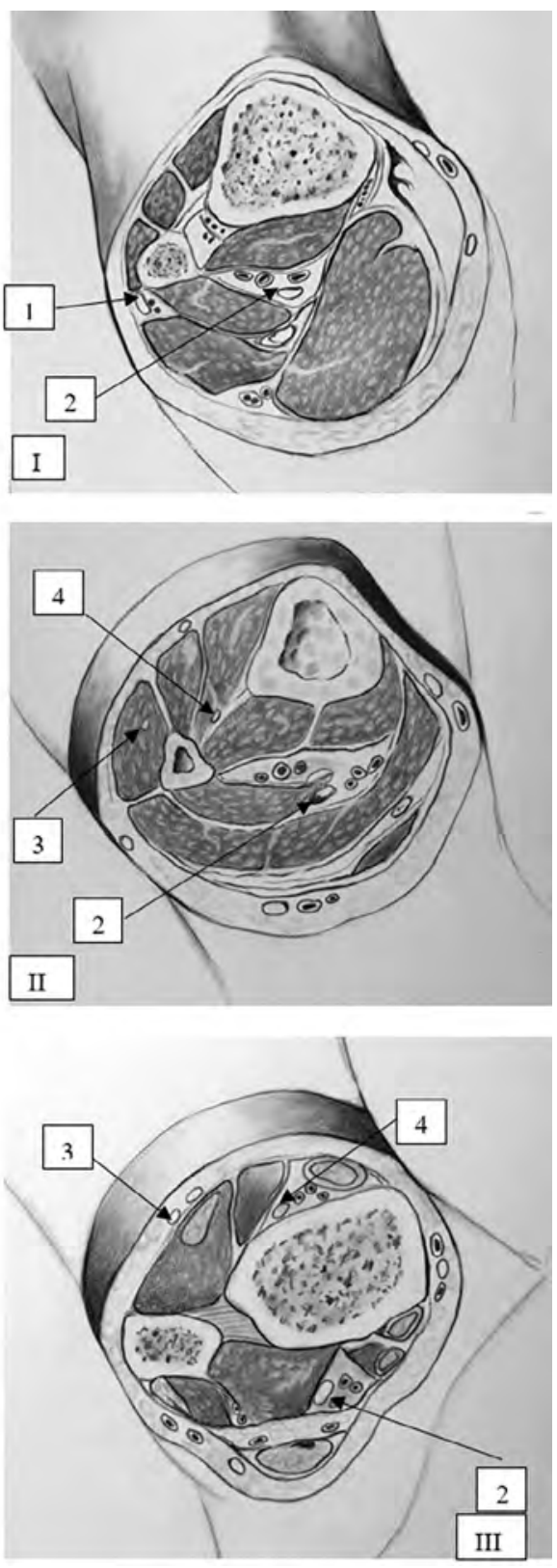

Fig. 2 - Topography of the nerves of the leg muscles on a total cut. Mature age, right limb. Drawing of the preparation

Notes: I - upper third; II - middle third; III - lower third. 1 - common peroneal nerve; 2 - tibial nerve; 3 - superficial; 4 - deep peroneal nerve 
Such differences in the location of the leg muscles of an adult and of one-month-old baby undoubtedly related to the fact that the child's muscular belly is longer in relation to the tendon.

We studied the histotopography of intramuscular nerves on total transverse sections of antagonistic muscles: flexor and extensor digitorum longus, longus flexor and extensor of the big toe, and also investigated the spectrum of myelin fibers contained in these nerves in a one-month-old baby and an adult. These studies have shown that the nerves of the leg muscles have features both in the quantitative and qualitative composition of the conductors that form them.

On their way in the thickness of the muscle, the main nerve trunks, as evidenced by macromicroscopic preparations, give a large number of lateral branches, which makes it difficult to accurately count the myelin fibers. Therefore, only the major intramuscular nerve trunks have been studied.

On histotopographic sections of the extensor digitorum longus nerve in a one-month-old baby, thick-diameter myelin fibers are absent, whereas in the long finger flexor nerve, on average, they are $0.5 \%$. The number of thin and medium is respectively $8 \%, 13 \%$ and $83.5 \%, 16 \%$.

In the longus extensor nerve of the big toe, the number of thick fibers is $0.8 \%$, medium $-15 \%$, thin $84 \%$, in the long flexor nerve of the big toe $-1 \%, 19 \%$ and $80 \%$, respectively. None of the muscle nerves of myelin fibers of a very thick diameter were found.

In adulthood, the spectrum of myelin fibers changes. So, in the nerve of the long extensor of the fingers, the ratio of very thick, thick, medium and thin fibers is $5 \%, 12 \%, 43 \%$ and $40 \%$, and in the nerve of the long flexor of the fingers - respectively $5.3 \%, 13.7 \%, 40 \%$ and $41.3 \%$. In the nerve of the extensor longus and longus flexor of the big toe $-6 \%, 11 \%, 45 \%, 38 \%$ and $7.2 \%, 13.4 \%, 41 \%, 38.4 \%$, respectively.

Comparing the digital indicators of the flexor and extensor nerves, we found some differences: in the nerves of the flexor muscles, the set of nerve fibers is more diverse (with a slight predominance of the number of medium, thick and very thick fibers), which is apparently associated with the peculiarity of their functions, it is known that the flexor muscles are always more developed than the extensors.
Thus, the study of the nerves of the leg muscles using the methods of total cross-sections and histotopography (in combination with the data of macromicroscopic studies) allowed us to clarify the course of the neurovascular bundle of the leg at its three levels, taking into account individual age characteristics, and also to show the myeloarchitectonics of both the main nerve trunks and their intramuscular branches. The latter may be of undoubted interest in the clinic of microsurgery and acupuncture.

There are a number of studies in the literature on the distribution of nerves and blood vessels in the thickness of the leg muscles [1, 2]. However, these authors, describing the topography of the main nerve trunks in the thickness of the muscle, did not pay due attention to the forms of individual anatomical variability in the distribution of intraorganic nerves. At the same time, clinicians pay special attention to variability in the distribution of nerves when developing new operational approaches to the nerve trunks in neuroand myoplastic operations [5, 6, 9].

In this regard, in our macro-microscopic study, the main attention was paid to the individual anatomical variability in the innervation of the lower leg muscles.

\section{Conclusion}

1. The nerves of the leg muscles have features both in quantitative and qualitative composition of the conductors forming them.

2. In the nerves of the flexor muscles, the set of nerve fibers is more diverse (with a slight predominance of the number of medium, thick and very thick fibers), which is associated with the peculiarity of their functions.

3. In adulthood, the \% ratio in the spectrum of myelin fibers in the nerves of the lower leg changes significantly.

Perspectives of further research. We consider it expedient to start studying the features of myelination of the nerves of the muscles of the lower extremities in different age groups. The patterns of individual anatomical variability of the nerves of the lower extremities can be of undoubted interest in the clinic of microsurgery and acupuncture.

\section{References}

1. Prishlyak A, Reminetskiy B, Stahurskaya I, Shur O. Nekotorie variant krovosnabzhenia i innervatsii yagodichnix $i$ zadnix otdelov bedra y ploda [Some variant of blood supply and innervation of the gluteus and the back of the thigh and fetus]. Biomeditsinskaya i biosotsialnaya antropologia. 2017;26:92-94. [Russian]. PMID: 29017334. doi: $10.1177 / 1039856217732473$

2. Dzhahisvili NA. Spinnomozgovye nervnue spletenia i sympaticheskiy stvol cheloveka [Human spinal plexus and sympathetic trunk]. Akademia nauk Gruzii. Institut eksperimentalnou medicinu. Institut eksperimentalnoy morfologii. Sbornik nauchnux trudov. Tbilisi; 2009. p. 260-263. [Russian]

3. Tzika M, Paraskevas GK, Kitsoulis P. The accessory deep peroneal nerve: a review of the literature. Foot (Edinb). 2012;22(3):232-4. PMID: 22795551. doi: 10.1016/j.foot.2012.05.003 
4. Magistris MR, Truffert A. Extensor digitorum brevis innervated by the tibial nerve ("all tibial foot"): anomalous innervation or technical pitfall? Muscle Nerve. 1997;20(7):906-8.

5. Schnabel A, Middendorf B, Boschin MG, GottschalkA, Van Aken H, Zahn PK, et al. Vergleich der Analgesiequalit t und Komplikationen von ultraschall- und nervenstimulatorgesteuerten peripheren Nervenkathetern [Differences of analgesic efficacy and complication rates between ultrasound and nervestimulator guided peripheral nerve catheters : Database analysis on patient-relevant target parameters]. Anaesthesist. 2014 Sep 18;63(11):82531. [German]. PMID: 25227880. doi: 10.1007/s00101-014-2379-7

6. Vasilenko PB. Blokada sedalishchnogo nerva podkolennym dostupom [Blockade of the sciatic nerve by the popliteal access]. Biomeditsinskiy zhurnal. 2005;6(23)74-75. [Russian]

7. Zabusov AV, Yasnev DS, Larionov SV. Kompleksnaya analgeziya perioperatsionnogo perioda s primeneniem dalargina pri operatsiyakh na stope i nizhnyei treti goleni [A comprehensive perioperative analgesia using dalargin during operations on the foot and lower third of the tibia]. V kn: Devyatyi s'ezd federatsii anesteziologovreanimatologov. Tezisy dokladov. Irkutsk; 2004. 2004. s. 379-380. [Russian]

8. Taraskin AF, Polyaev VO, Popov AYu. Conducting anesthesia of extremities. Practical medicine; 2007. p. 51.

9. Vloka JD, Hadi A, April E, Thys DM. The Division of the Sciatic Nerve in the Popliteal Fossa: Anatomical Implications for Popliteal Nerve Blockade. Anesth Analg. 2001 Jan;92(1):215-7. PMID: 11133630. doi: 10.1097/00000539-200101000-00041

10. Fornage BD. Peripheral nerves of the extremities: imaging with US. Radiology. 1988 Apr;167(1):179-82. PMID: 3279453. doi: 10.1148/radiology.167.1.3279453

\section{УДК 611.98:616-089.11}

\section{МАКРО-МИКРОСКОПИЧЕСКИЕ ОСОБЕННОСТИ ИННЕРВАЦИИ МЫЩЦ ГОЛЕНИ}

Терещенко А. А., Шиян Д. Н., Олянич С. О.

Резюме. Цель. Изучить топографоанатомические особенности иннервации мышц голени человека.

Материал и методы. На трупном материале 15 объектов лиц зрелого возраста и ребенка 1 месяца изучены вне- и внутримышечные нервы голени на трёх уровнях: верхней, средней и нижней третях. Использованы методы распилов голени по Н.И. Пирогову, методика гистотопографических срезов, макромикроскопический метод, гистологический - окраска гематоксилином и эозином, и по Крутсай.

Результаты. Изучение нервов мышц голени методами тотальных распилов и гистототопографии (в комплексе с данными макромикроскопических исследований) позволило нам уточнить ход сосудисто-нервного пучка голени на ее трех уровнях с учетом индивидуальных возрастных особенностей, а также показать миелоархитектонику как основных нервных стволов, так и их внутримышечных ветвей.

Изучена гистотопография внутримышечных нервов на полных поперечных срезах мышц-антагонистов: длинного сгибателя и разгибателя пальцев, длинного сгибателя и разгибателя большого пальца стопы, а также описан спектр миелиновых волокон, содержащихся в этих нервах у месячного ребенка и взрослого зрелого возраста.

На гистотопографических срезах длинного разгибателя пальцев у месячного ребенка миелиновые волокна толстого диаметра отсутствуют, тогда как в нерве-сгибателе длинного пальца в среднем они составляют 0,5\%. Количество тонких и средних - соответственно 8\%, 13\% и 83,5\%, $16 \%$.

Также выявлены особенности индивидуальной анатомической изменчивости расположения сосудов по отношению к основным нервным стволам, а также различия в топографии нерва в соответствующих мышцах.

Выводы. В нервах мышц голени обнаружены особенности, как в количественном, так и в качественном составе образующих их проводниках; в нервах мышц-сгибателей состав нервных волокон более разнообразный (с незначительным преобладанием количества средних, толстых и очень толстых волокон), что связано с особенностью их функций; в зрелом возрасте значительно изменяется \% соотношение в спектре миелиновых волокон в нервах голени.

Ключевые слова: большеберцовый нерв, мышцы голени, иннервация, человек.

\section{УДК 611.98:616-089.11}

\section{МАКРО-МІКРОСКОПІЧНІ ОСОБЛИВОСТІ ІННЕРВАЦІЇ М'ЯЗІВ ГОМІЛКИ}

Терещенко А. О., Шиян Д. М., Оляніч С. О.

Резюме. Мета. Дослідити топографоанатомічні особливості іннервації м'язів гомілки людини.

Матеріал та методи. На трупному матеріалі 15 об'єктів осіб зрілого віку та дитини 1 місяця вивчені поза- та внутрішньом'язові нерви гомілки на трьох рівнях: верхньої, середньої і нижньої третин. Використані методи розпилювання гомілки за М.І. Пироговим, методика гістотопографічних зрізів, макро-мікроскопічний метод, гістологічний - забарвлення гематоксиліном і еозином, та за Крутсай. 
Результати. Вивчення нервів м'язів гомілки методами тотальних розпилів та гістототопографії (в комплексі з даними макромікроскопічних досліджень) дозволило нам уточнити хід судинно-нервового пучка гомілки на трьох її рівнях із урахуванням індивідуальних вікових особливостей, а також показати мієлоархітектоніку, як основних нервових стовбурів, так і їх внутрішньом'язових гілок.

Вивчено гістотопографрію внутрішньом'язових нервів на поперечних зрізах м'язів-антагоністів: довгого згинача та розгинача пальців, довгого згинача та розгинача великого пальця стопи, а також описаний спектр мієлінових волокон, що містяться в цих нервах у місячної дитини та дорослого зрілого віку.

На гістотопографічних зрізах довгого розгинача пальців у місячної дитини мієлінові волокна товстого діаметра відсутні, тоді як у нерві-згиначі довгого пальця в середньому вони становлять $0,5 \%$. Кількість тонких та середніх - відповідно 8\%, 13\% та 83,5\%, $16 \%$.

Також виявлено особливості індивідуальної анатомічної мінливості розташування судин по відношенню до основних нервових стовбурів, а також відмінності у топографії нерва у відповідних м'язах.

Висновки. У нервах м'язів гомілки встановлені особливості як у кількісному, так і в якісному складі провідників, що їх утворюють; у нервах м'язів-згиначів склад нервових волокон різноманітніший (з незначним переважанням кількості середніх, товстих і дуже товстих волокон), що пов'язано з особливістю їх функцій. У зрілому віці значно змінюється \% співвідношення у спектрі мієлінових волокон у нервах гомілки.

Ключові слова: великогомілковий нерв, м'язи гомілки, іннервація, людина.

\section{ORCID and contributionship:}

Anatoliy O. Tereshchenko : B, C, F

Denys M. Shyian : 0000-0002-3755-7051 A, B, D

Sergey O. Olyanich : E,F

A - Work concept and design, B - Data collection and analysis,

C - Responsibility for statistical analysis, D - Writing the article,

E - Critical review, F - Final approval of the article

\section{CORRESPONDING AUTHOR}

\section{Denys M. Shyian}

Kharkiv, Kharkiv national medical university,

Human Anatomy Department

4, Nauky avenue, Kharkiv 61022, Ukraine

tel: +380996585187, e-mail: dm.shyian@knmu.edu.ua

The authors of this study confirm that the research and publication of the results were not associated with any conflicts regarding commercial or financial relations, relations with organizations and/or individuals who may have been related to the study, and interrelations of coauthors of the article. 